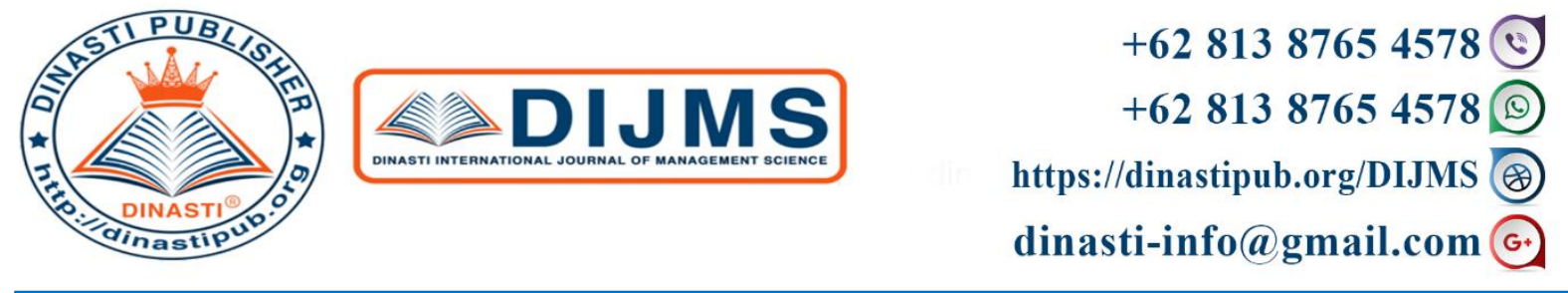

\title{
APPLYING GENERIC STRATEGY IN CREATING CUSTOMER LOYALTY IN THE MIDDLE OF PANDEMI VIRUS COVID-19 IN POLYCLINIC MCU XYZ CARDIOVASCULAR HOSPITAL
}

\section{Mastari}

Mercu Buana University, Jakarta, Indonesia

\begin{tabular}{|c|c|}
\hline $\begin{array}{l}\text { RTICLE INFORMATION } \\
\text { Received: } 17^{\text {th }} \text { May } 2020 \\
\text { Revised: } 20^{\text {th }} \text { June } 2020 \\
\text { Issued: } 19^{\text {th }} \text { July } 2020 \\
\text { Corresponding author: } \\
\text { Mastari } \\
\text { E-mail: } \\
\text { mastari865@gmail.com } \\
\end{array}$ & $\begin{array}{l}\text { Abstract: Background this study is to find the } \\
\text { importance of the application of strategy generic } \\
\text { consisting of the strategy differentiation, strategy cost } \\
\text { leadership and strategies focus on created customer } \\
\text { loyalty in the centre of the condition pandemics an } \\
\text { outbreak of the disease covid-19 in polyclinic MCU } \\
\text { XYZ Cardiovascular Hospital in determine policy in } \\
\text { order to anticipate the increasing number of patients } \\
\text { move to the hospital in the middle of this other } \\
\text { industrial competition hospitals that getting high. } \\
\text { Research methods that were used with the quantitative } \\
\text { approach, subject to a sample research that is } 82 \\
\text { patients. Data were collected by means of instruments } \\
\text { the questionnaire measured by scale Likert and in } \\
\text { analysis with linear regression multiple with the result } \\
\text { that the application of strategy differentiation having } \\
\text { influence positive impact in creating customer loyalty } \\
\text { in polyclinic MCU XYZ Cardiovascular Hospital, } \\
\text { shown through value the regression coefficient ( b1 = } \\
\text { 0,381 and t count }=4,444 \text { with sig < } 0,05 \text {. } \\
\text { Keywords: the generic strategy created customers } \\
\text { loyalty polyclinic MCU XYZ Cardiovascular Hospital }\end{array}$ \\
\hline
\end{tabular}

\section{INTRODUCTION}

At the end of the end of the year 2019 exactly in December, of the world population in gemparkan with the appearance of a virus that was given the name Corona in the city of wuhan Tiongkok china, the emergence of this virus highly dangerous and has claimed many fatalities in the city. Virus spread is like this very fast through direct interaction between humans and through the air, this virus spread so far almost countries including 
Indonesia. This makes some countries implementing policies to impose lockdown in order to prevent corona virus. In Indonesia government has applied a policy large-scale social restraints (PSBB) to reduce this virus. But, it is also can cause severe respiratory infection, such as pneumonia, middle-east (MERS) respiratory syndrome and severe acute respiratory syndrome (SARS) Government announced that the virus covid-19 entered indonesia 2020 with early this month found to the two patients positively infected this virus.Based on information the government through the National Disaster Management Authority (BNPB),through is an formed by the government that starting from early March until April 302020 at $6 \mathrm{pm}$ through press conference in television station, the number of patients that a virus infected positf on the remaining 10.118.Person with the number of patients who is recovering were the 1,522 people and patients have already died were 792 people. Infected patients estimated growth rate continues to rise quickly as an increase in the screaning melaui methods by the government rapid test corona .A variety of the strategy took by indonesian government in handling prevent the spreading of this virus, as social distanting appeal, phisycal distancing, work from home (WFH), school from home and served in the house.The impact of the pandemic is quite high, various economic difficulty the industrial sector affected the operational and financial government policy movement in issuing the restriction regulation to prevent the activities this virus. Not a few of the company that houses while their employees even do the laying off of because of difficulty due to financial covid-19 pandemic virus. Similar felt the impact in the health sector as hospital, the number of patients do medical checkup due to this pandemic.Based on the data were drawn from polyclinic MCU XYZ Cardiovascular Hospital Show the very significant if taken the data for three months of service and compared data three months before.

\begin{tabular}{|c|c|c|}
\hline \multirow{2}{*}{ Month } & \multicolumn{2}{|c|}{ Year } \\
\cline { 2 - 3 } & $\mathbf{2 0 1 9}$ & $\mathbf{2 0 2 0}$ \\
\hline January & 165 & 159 \\
\hline February & 143 & 167 \\
\hline March & 152 & 90 \\
\hline April & 168 & 33 \\
\hline Ammount & 628 & 449 \\
\hline
\end{tabular}

Picture 1. Patient Data MCU XYZ Cardiovascular Hospital

Source: Polyclinic MCU XYZ Cardiovascular Hospital (2020)

When the pandemic virus covid-19 another thing that causes a reduction in the number of patients that arrived to medical checkup in the increasing level of competition hospital in providing health services. The hospital in indonesia in every period of increasingly rapidly especially for private hospitals. This can be seen from the following data . 


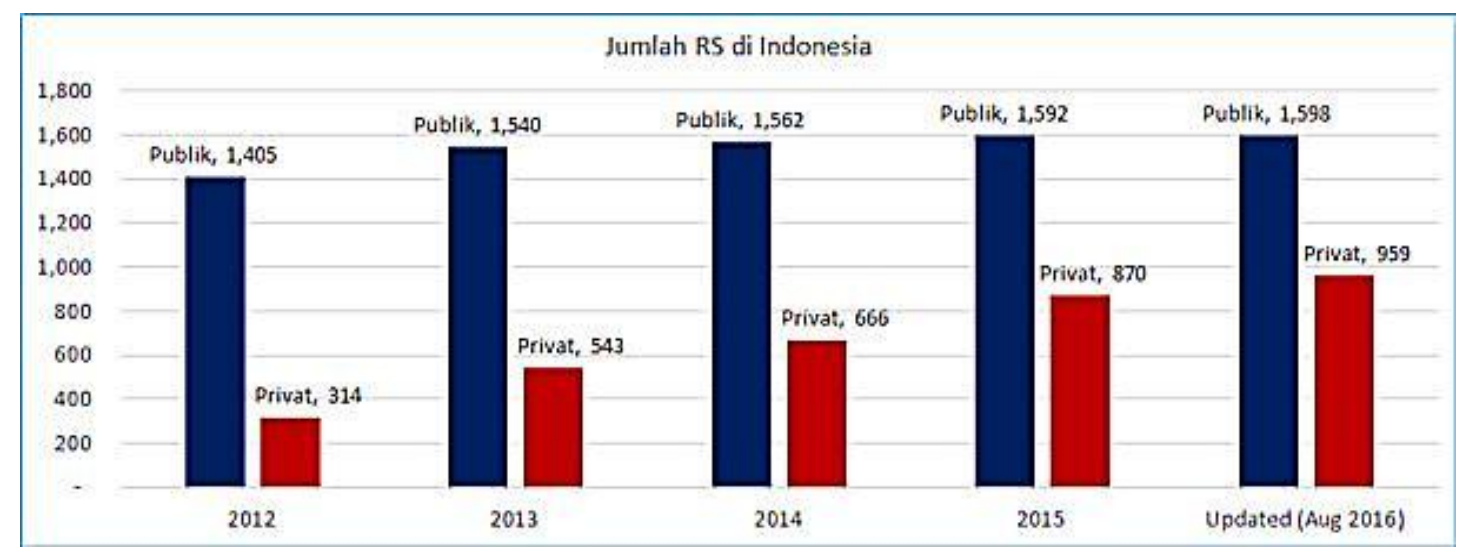

Picture 2. Hospital Growth in Indonesia

Data on increased public hospital for 5 years has not fast growing private hospitals. The average growth of the public hospital of $3 \%$, while the private hospitals by $34 \%$. This makes competition gets tougher in the hospital .To be able to compete with other hospital, cardiovascular hospital xyz must have a customer loyalty that having high so patients did not turn to another hospital in (MCU) memelakukan medical checkup .In creating customers loyal hospital services must have the right to create inovasi-inovasi hoping consumers will feel they own mindset that there was something missing if not come back to the polyclinic MCU XYZ Cardiovascular Hospital to perform medical checkup (MCU).

\section{LITERATURE STUDY}

\section{Strategic Management}

Management strategy is a process consisting of three activities including formulating strategies, the implementation of the strategy and evaluation strategies. The process management strategy objective can be explained as a proxy, logical, systematic to make big decision by in an organization. This process seeks to organize qualitative and quantitative information in a way that allows effective decision taken in disarray. The implementation of the strategy requires companies to set annual target, equip with policy , motivate employees and allocate resources and strategy formulated can be implemented. According to David (Fred R. David, 2011), management strategy can be defined as the art and science to draw up, the implementation of , and evaluation cross-keputusan functional tujuan-tujuan that allows organizations to achieve this .This definition is that management focused on integrating strategic management, marketing, financial accounting, production operation, research and development and information systems organizations to achieve success. Each company has business strategy in determining the direction of the vision and mission to be achieved, the process of applying the company has a different strategy. One of a strategy often applied by the company is porter generic strategy.

\section{Porter Generic strategy}


Porter generic strategy strategy is generally used by a corporation in running business to reach and maintain advantage. Michael porter explained that 3 type strategy is generally used by the business to reach and maintain ability and competition.Third this strategy distinguished by scope of strateginya and ability of strategy.Scope strategy viewed from the side demand and also be seen of big and the composition of want to a market.Ability seen from the supply side strategy owned and seen from capability of company.Model generic strategy first raised by porters (1980), this method use an approach strategy firm in order to win over similar competitors in industry. In practice after the company knows the generic, in their implementation will be followed by the determination of strategy more operational. According to Michael R. Porter, as quoted Husein Umar (2003) said that strategy: generic divided into three categories.

\section{Differentiation strategy}

Differentiation strategy is efforts or actions of a company to devise or invent a difference on both wrap their products, the quality, a brand or color with a distinguishing quotes from competitors that formed the best value to customers for sale won a The differentiation is a strategy to defend customer loyalty where using the strategies differentiation, customers scoring more compared to other products . One of the ways people to gain a differentiation is to integrate content, the context and infrastructure company that will have to value more companies offer to customers ccording to kotller and armstrong ( 2012 ), there are several parameters or dimensions in making a, product differentiation, that is :

A Form diversity is capability products to be distinguishing competitors similar to the product.

A Quality of performance refers to the level at which all units produced are identical and meet the specifications of the target being reached.

A Decide on a product that won't solve the damage or fail in a certain period.

A Ease of repairing products that repair or damage.

A Product appearance models in the eyes of consumers can show the appearance and feelings caused by products for consumers.

A The design in differentiating and promoting the company's products and services with competitive products.

A Product durability added length of time Benefits of the product obtained by consumers for the product.

A The uniqueness of the products offered with a variety of uniqueness, namely the characteristics that complete the product function

\section{Cost Leadership strategy}

This strategy is a strategy to become a producer with low prices in certain industries with a certain level of quality. Some of the steps taken by the company to achieve 
advantages in the field of prices are to develop business process efficiency, get special access to reach many sources of raw materials but have low prices, build outsourcing and vertical integration that is more optimal or by reducing some costs that are not overall importance from every aspect of the company. Factors that must be owned by the company if you want to successfully implement this strategy include:

A Have Enough corporate finance to provide significant investment in production and sales

A Have a good ability in designing products so that the production process becomes more efficient.

A Experts are quite high in terms of building the manufacturing process.

A Have an efficient distribution channel

\section{Focus Strategy}

This strategy is only focus on one particular segment in the market and in that segment the company strives to achieve excellence both in terms of cost or in terms of differentiation. This strategy has the idea that the needs of the group will be more achieved and get better services by only focusing on the group. Companies that use this focus strategy generally feel a high level of loyalty from their customers and this loyalty makes other companies hesitate to compete directly. companies with this strategy focus on certain segments, the company has a lot of customers that are not too many and makes the power to bargain for goods from suppliers to be low. Companies that succeed in a focus strategy are able to make a product that is actually intended for the public into a smaller segment that they can understand well. Some risks that arise by using this strategy are the appearance of imitations of the product and the change in demand for the segments that are themarketingobjectives.

\section{Customer loyalty}

Customer loyalty is a strong and inherent commitment from customers to return and be consistent with products and services. According to Rahmayanty (2010: 13), loyalty is about the percentage of people who have bought within a certain time frame and made a repeat purchase since the first purchase. Often the length of time a customer purchases a product with that company and purchases repeatedly, used as a measure of loyalty. In this case, loyalty is equated or even defined as a percentage of total spending in the product or service category. Based on the expert's understanding above, it can be concluded that customer loyalty is the basis of the company to survive and face competitors 


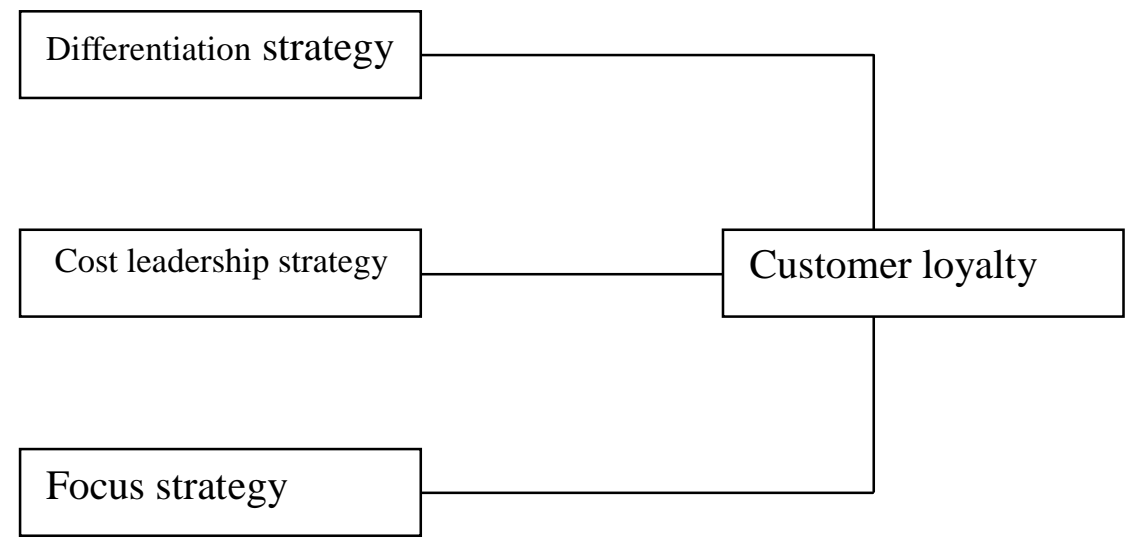

Picture 3. Framework

\section{RESEARCH METHODS}

Porter's generic strategy model development method in this study uses research and development methods. Literature study method to collect secondary data while survey methods through questionnaires to collect primary data. The survey method in data collection was taken from the total number of patients who still came to perform medical checkup services in January-April 2020, starting from the enactment of a large-scale social limitation (PSBB) by the DKI Jakarta city government in April 2020 as many as 449 patients. The questionnaire survey method was conducted via telephone and social media WhatsApp based on registered cellular number data, for data processing using the Excel format and Statistical Package for Social Sciences (SPSS), the data collection process was carried out in 1 week in May 2020. The number of samples in the study This is determined by the Slovin formula quoted by Riduan and Kuncoro (2014: 49), namely:

$$
\mathrm{n}=\frac{\mathrm{N}}{1+\left(\mathrm{N} \mathrm{e}^{2}\right)}
$$

Where :

$$
\mathrm{n}=\text { Number of samples }
$$

$\mathrm{N}=$ total population

$\mathrm{e}=$ Precision (set at $10 \%$ with a confidence level 95\%)

$\mathrm{n}=\underline{449}$

$$
1+(449 \mathrm{x} 0,01)
$$

$\mathrm{n}=\underline{449}$

$$
1+4,49
$$

$\mathrm{n}=\underline{449}$

$$
5,49
$$

$\mathrm{n}=82$

Based on the calculation of the number of samples using the Slovin formula, the number of respondents in this study was 82 respondents. The assessment of the rating of each 
indicator is done by giving the same number of questions to respondents. In determining this score a Likert scale is used with five rating categories, namely:

1. Score 5 answers totally agree

2. Score 4 answers agree

3. Score 3 answers is quite agree

4. Score 2 answers disagree

5. Score 1 strongly disagrees

Whereas the concept of the questions given to respondents was related to the generic strategy carried out by XYZ cardiac hospital medical checkups regarding the application of generic strategies in creating customer loyalty in the midst of the co-19 pandemic.

\section{RESULTS AND DISCUSSION}

Pandemic outbreak of the covid-19 virus does have a very big impact on all sectors of life, especially in the health sector and the economy, in the health sector everyone has a high awareness to conduct health checks this is what causes all hospitals to be increasingly crowded by patients who are visited want to check his health. On the other hand the application of the large-scale social restriction policy (PSBB) by the government in order to break the chain of the spread of the covid-19 virus had an impact on economic hardship for the community, many industrial sectors and companies were closed so that there were job cuts everywhere. Seeing the situation that was happening in the environment a variety of strategies applied by the hospital management. XYZ cardiac hospital in maintaining the number of patient visits at a poly medical checkup (MCU) in the midst of a pvidemic of the covid-19 virus outbreak.

\section{Differentiation Strategy Polyclinic MCU Cardiovascular Hospital XYZ}

The differentiation strategy is the company's effort or action to design or create a difference in the product in terms of packaging, quality, brand or color with the aim of differentiating offers from competitors in order to form the best value to customers to win sales competition. The differentiation strategy is a strategy that can maintain customer loyalty where by using a differentiation strategy, customers get more value when compared to other products (Kotler, 2007). The strategy applied in this case

A Provide inspection services with the concept of one stop service

A Basic examination related to heart disease is given in full

A The doctor who carries out the examination involves an internal medicine doctor, heart, lung and nutrition

A Registration system and agreement for MCU can be done online through the application

\section{Strategi Cost Leadership Polyclinic MCU Cardiovascular Hospital XYZ}

This strategy is a strategy to be a low-cost service in the inspection of high-quality 
MCU. The hospital will provide a variety of service products with price quotes with the aim of getting higher profits from its competitors. In the event of a price competition, the hospital can still maintain profits. The strategy applied in this case:

A Providing a package price program for MCUs during the co-19 pandemic (three months from April 2020)

A Providing special tariff packages for companies that collaborate with hospitals in conducting MCU for the employees of these companies

A Conduct a gift-giving program for patients who can provide recommendations to other patients to perform MCU

A Pembayaran Payment methods can use all types of health insurance and provide discounted rates to the participants of the health insurance

A Give a package price rate that varies according to the patient's ability

\section{Focus Strategy Polyclinic MCU Cardiovascular Hospital XYZ}

This strategy is used to build competitive advantage in a narrower market segment. This type of strategy is intended to serve the needs of consumers whose numbers are relatively small and in making their decision to buy relatively unaffected by price. The strategy applied in this case

A Types of MCU services are only focused on heart disease and its causes

A MCU services are focused on one place in the executive poly and not mixed with other Polyclinic.

A MCU inspection tools have the latest technology and are supported by experts in their fields

A Comfortable and clean inspection facilities and waiting rooms.

\section{Strategies for creating customer loyalty Polyclinic MCU Cardiovascular Hospital XYZ}

Customers are the company's most valuable assets, without company customers it will be difficult to grow and even survive. The amount of customer loyalty will not be separated from the satisfaction obtained from the product or service from the brand. Therefore, customer satisfaction is a must. Customer satisfaction is a level where the needs, desires and expectations of customers can be met which will result in repurchases or continued loyalty (loyalty). The strategy applied in this case:

A Maintaining the quality of service by increasing human resources in the MCU unit

A Carry out maintenance of MCU supporting medical devices so that they always provide acute damage results for each examination

A Always maintain good relations with customers on an ongoing basis

A Conduct periodic evaluations to see constraints in providing services to customers.

A Provide services that are sympathetic and empathetic to patients

A Provide complete facilities and facilities to support services 
Based on the description of the strategy above, the writer writes the concept of the questions raised to the customer respondents as follows:

\begin{tabular}{|c|c|}
\hline No & $\begin{array}{l}\text { Questions regarding differentiation strategies Polyclinic MCU Cardiovascular Hospital } \\
\text { XYZ }\end{array}$ \\
\hline 1 & Poly MCU provides inspection services with the concept of one stop service \\
\hline 2 & Basic examination related to heart disease is given in full \\
\hline 3 & $\begin{array}{l}\text { Doctors and nurses who carry out the examination only involve doctors in internal } \\
\text { medicine, heart, lung and nutrition }\end{array}$ \\
\hline \multirow[t]{2}{*}{4} & $\begin{array}{l}\text { Is the registration system and agreement for the MCU can be done online through the } \\
\text { application }\end{array}$ \\
\hline & Questions related to Polyclinic MCU Cardiovascular Hospital XYZ \\
\hline 5 & $\begin{array}{l}\text { How about offering a package price program for MCUs during the co-19 pandemic } \\
\text { (three months from April 2020) }\end{array}$ \\
\hline 6 & $\begin{array}{l}\text { If you provide a special tariff package for companies that cooperate with hospitals in } \\
\text { conducting MCU for employees of these companies }\end{array}$ \\
\hline 7 & $\begin{array}{l}\text { How about doing a gift-giving program to patients who can provide } \\
\text { recommendations to other patients to do } \mathrm{MCU}\end{array}$ \\
\hline 8 & $\begin{array}{l}\text { What if the payment method can use all types of health insurance and given a } \\
\text { discount to the participant of the health insurance }\end{array}$ \\
\hline \multirow[t]{2}{*}{9} & Price rates vary according to the ability of the patient \\
\hline & Questions related to Polyclinic MCU Cardiovascular Hospital XYZ \\
\hline 10 & Is this type of MCU service only focused on heart disease and its causes \\
\hline 11 & $\begin{array}{l}\text { MCU services are focused on one place in executive poly and not mixed with other } \\
\text { poly }\end{array}$ \\
\hline 12 & $\begin{array}{l}\text { The quality of MCU inspection equipment has the latest technology and is supported } \\
\text { by experts in their fields }\end{array}$ \\
\hline \multirow[t]{2}{*}{13} & Facilities for inspection and a comfortable and clean waiting room. \\
\hline & Questions related to customer loyalty Polyclinic MCU Cardiovascular Hospital XYZ \\
\hline 14 & Does poly MCU maintain the quality of service by increasing HR in its work units \\
\hline 15 & $\begin{array}{l}\text { Perform maintenance of medical devices supporting the MCU to always provide } \\
\text { results of acute damage every examination }\end{array}$ \\
\hline 16 & Always maintain a good relationship with customers on an ongoing basis \\
\hline 17 & Conduct periodic evaluations to see the obstacles in providing services to customers \\
\hline 18 & Providing services that are sympathetic and empathet \\
\hline
\end{tabular}


19 Provide complete facilities and facilities to support services

Data in this study were collected through distributing questionnaires to patients as researchsubjects. Patient responses regarding each question in the questionnaire are presented as follows.

Research Data Description

\begin{tabular}{|c|c|c|c|c|c|c|c|}
\hline \multirow[t]{2}{*}{ Indicator } & \multirow[t]{2}{*}{ No.item } & \multicolumn{5}{|c|}{ Answer Value } & \multirow[t]{2}{*}{ Amount } \\
\hline & & STS & TS & CS & S & SS & \\
\hline \multirow{6}{*}{$\begin{array}{c}\text { Differentiation } \\
\text { strategy }\end{array}$} & 1 & 0 & 1 & 24 & 41 & 16 & 82 \\
\hline & 2 & 0 & 1 & 14 & 47 & 20 & 82 \\
\hline & 3 & 0 & 3 & 15 & 41 & 23 & 82 \\
\hline & 4 & 0 & 1 & 14 & 45 & 22 & 82 \\
\hline & Amount & 0 & 6 & 67 & 174 & 81 & 328 \\
\hline & Percentage & $0.0 \%$ & $1.8 \%$ & $20.4 \%$ & $53.0 \%$ & $24.7 \%$ & $100 \%$ \\
\hline \multirow{8}{*}{$\begin{array}{c}\text { cost leadership } \\
\text { strategy }\end{array}$} & 5 & 0 & 2 & 8 & 47 & 25 & 82 \\
\hline & 6 & 0 & 0 & 9 & 46 & 27 & 82 \\
\hline & 7 & 0 & 0 & 15 & 46 & 21 & 82 \\
\hline & 8 & 0 & 1 & 13 & 38 & 30 & 82 \\
\hline & 9 & 0 & 0 & 19 & 39 & 24 & 82 \\
\hline & 10 & 0 & 0 & 13 & 48 & 21 & 82 \\
\hline & Amount & 0 & 3 & 77 & 264 & 148 & 492 \\
\hline & Persentase & $0.0 \%$ & $0.6 \%$ & $15.7 \%$ & $53.7 \%$ & $30.1 \%$ & $100 \%$ \\
\hline \multirow{7}{*}{ focus strategy } & 11 & 0 & 2 & 15 & 48 & 17 & 82 \\
\hline & 12 & 0 & 0 & 12 & 41 & 29 & 82 \\
\hline & 13 & 0 & 4 & 6 & 47 & 25 & 82 \\
\hline & 14 & 0 & 1 & 16 & 41 & 24 & 82 \\
\hline & 15 & 0 & 1 & 15 & 47 & 19 & 82 \\
\hline & Amount & 0 & 8 & 64 & 224 & 114 & 410 \\
\hline & Percentage & $0.0 \%$ & $2.0 \%$ & $15.6 \%$ & $54.6 \%$ & $27.8 \%$ & $100 \%$ \\
\hline
\end{tabular}




\begin{tabular}{|c|c|c|c|c|c|c|c|} 
& & & & & & & \\
& 16 & 0 & 1 & 14 & 40 & 27 & 82 \\
17 & 0 & 4 & 18 & 34 & 26 & 82 \\
\hline \multirow{3}{*}{ Customer loyalty } & 18 & 0 & 1 & 16 & 39 & 26 & 82 \\
& 19 & 0 & 1 & 11 & 43 & 27 & 82 \\
& Amount & 0 & 7 & 59 & 156 & 106 & 328 \\
& Percentage & $0.0 \%$ & $2.1 \%$ & $18.0 \%$ & $47.6 \%$ & $32.3 \%$ & $100 \%$ \\
\hline
\end{tabular}

The data in the table above shows that overall respondents' responses regarding the implementation of differentiation strategies are dominated by agreeing answers with a percentage of $53 \%$, but there are still respondents who give disagreeing answers $20.4 \%$ and some even giving disagreeing answers namely $1.8 \%$. Meanwhile, for the implementation of the cost leadership strategy and focus strategy, most respondents also gave agreed responses related to the items in the questionnaire.

\section{Test Validity and Reliability of the Questionnaire}

Questionnaires that can be used as research instruments are questionnaires that meet the validity and reliability requirements. Validity test is done by the product moment correlation formula, while the reliability test is done by Cronbach's alpha formula. The results of the questionnaire validity and reliability of each variable are presented as follows.

\section{Test Validity Questionnaire}

Test Validity Questionnaire

\begin{tabular}{lcccc}
\hline \multicolumn{1}{c}{ Variabel } & No. Item & $\mathbf{r}_{\text {count it }}$ & $\mathbf{r}_{\text {table }}$ & Explanation \\
\hline Differentiation & 1 & 0.766 & 0.2172 & Valid \\
strategy & 2 & 0.714 & 0.2172 & Valid \\
& 3 & 0.814 & 0.2172 & Valid \\
& 4 & 0.738 & 0.2172 & Valid \\
\hline Cost leadership & 5 & 0.640 & 0.2172 & Valid \\
strategy & 6 & 0.746 & 0.2172 & Valid \\
& 7 & 0.767 & 0.2172 & Valid \\
& 8 & 0.788 & 0.2172 & Valid \\
& 9 & 0.711 & 0.2172 & Valid
\end{tabular}




\begin{tabular}{llccc}
\hline & 10 & 0.699 & 0.2172 & Valid \\
\hline Focus strategy & 11 & 0.725 & 0.2172 & Valid \\
& 12 & 0.721 & 0.2172 & Valid \\
& 13 & 0.728 & 0.2172 & Valid \\
& 14 & 0.757 & 0.2172 & Valid \\
Customer & 15 & 0.683 & 0.2172 & Valid \\
loyalty & 16 & 0.709 & 0.2172 & Valid \\
& 17 & 0.795 & 0.2172 & Valid \\
& 18 & 0.770 & 0.2172 & Valid \\
& 19 & 0.734 & 0.2172 & Valid \\
\hline
\end{tabular}

Based on the table above, it appears that all statements have been declared valid. this is because all the questionnaire items already have the value of $r$ count $>r$ table. Meanwhile based on the reliability test also showed a reliable questionnaire with Crombach alpha> 0.7. Reliability measurements are carried out by means of one shot or a one-time measurement with the SPSS Cronbach Alpha statistical test $(\alpha)$. According to Nunnally in Ghozali (2016: 48), a construct or variable is said to be reliable if it gives a Cronbach Alpha value $>0.70$. As presented in the following table.

\section{Cronbach Alpha}

\begin{tabular}{lcc}
\hline \multicolumn{1}{c}{ Variabel } & Crombach's Alpha & Keterangan \\
\hline Strategi diferensiasi & 0.755 & Reliabel \\
Strategi cost leadership & 0.819 & Reliabel \\
Strategi fokus & 0.771 & Reliabel \\
Customer Loyalty & 0.743 & Reliabel
\end{tabular}

Thus obtained that all items has been declared valid and overall questionnaires have it is reliable , therefore fulfilled the criteria were as research instruments .

Multiple Linear Regression Test

The equation of multiple linear regression is as follows.

$\mathrm{Y}=\mathrm{a}+\mathrm{b} 1 \mathrm{X} 1+\mathrm{b} 2 \mathrm{X} 2+\mathrm{b} 3 \mathrm{X} 3+\mathrm{e}$

Where:
A $\mathrm{a}=$ Konstanta
A $b=$ Regression line coefficient
A $\mathrm{e}=$ error / confounding variable

Multiple linear regression tests have been carried out where through the results of the 
multiple linear regression tests obtained constant values and regression coefficients as presented in the following table

\begin{tabular}{|c|c|c|c|c|c|}
\hline & Model & $\begin{array}{l}\text { Unstandardiz } \\
\text { d Coefficient }\end{array}$ & $\begin{array}{l}\text { Standardized } \\
\text { Coefficients }\end{array}$ & & \\
\hline & & B & Std. Error & Beta & \\
\hline 1 & (Const & & $-0,696$ & 1,380 & \\
\hline & Strateg & erensiasi & 0,397 & 0,089 & 0,381 \\
\hline & Strateg & st leadership & 0,152 & 0,064 & 0,197 \\
\hline & Strateg & kus & 0,341 & 0,077 & 0,382 \\
\hline
\end{tabular}

Based on the data above, obtained constant values and regression coefficients that can be substituted in the following regression equation.

$\mathrm{Y}=\mathrm{a}+\mathrm{b} 1 \mathrm{X} 1+\mathrm{b} 2 \mathrm{X} 2+\mathrm{b} 3 \mathrm{X} 3+\mathrm{e}$

Customer Loyalty $=-0,696+0,381$ diferensiasi stategy $+0,197$ cost leadership stategy + 0,382 fokus stategy $+0,321$

Information:

1. Constant value (a) $=-0,696$ shows the principal value that has been owned by the customer loyalty indicator without the contribution of differentiation strategy, cost leadership strategy and focus strategy.

2. The value of the regression coefficient $(\mathrm{b} 1)=0.381$ shows that a change in the value of the role of the differentiation strategy by one point will increase the value of customer loyalty by 0.381 points.

3. The value of the regression coefficient $(b 2)=0.179$ shows that a change in value from the role of the cost leadership strategy by one point will increase the value of customer loyalty by 0.179 points.

4. The value of the regression coefficient (b3) $=0.382$ shows that a change in the value of the role of the focus strategy by one point will increase the value of customer loyalty by 0.382 points.

5. Error value $(e)=1-R$ Square $=1-0.679=0.321$ shows the contribution of the implementation of differentiation strategy, cost leadership strategy and focus strategy in determining customer loyalty.

\section{CONCLUSIONS AND RECOMMENDATIONS}

\section{Conclusion}

Covid-19 global pandemic has a huge impact on all business sectors, each business sector carries out various strategies in maintaining business continuity amid the co-19 
pandemic with the aim of still having loyal customers so that the company can survive amid current conditions. XYZ Cardiovascular Hospital which is a health service sector business entity continues to strive to continue to have loyal customers, differentiation strategies, cost leadership strategies and focus strategies continue to be developed following current conditions and customer needs in creating loyal customers so as to bring benefits to hospitals. In this study, the results show that the implementation of the differentiation strategy has the effect of a positive impact in creating customer loyalty in the hospital XYZ Cardiovascular Hospital, shown through the regression coefficient (b1) = 0.381 and $t$ arithmetic $=4.444$ with sig. $<0.05$. The implementation of the cost leadership strategy has a positive impact on creating customer loyalty in the XYZ Cardiovascular Hospital heart is shown through the regression coefficient (b2) $=0.197$ and $\mathrm{t}$ arithmetic $=$ 2.368 with sig. $<0.05$. And the implementation of a focus strategy has the effect of a positive impact in creating customer loyalty at the XYZ Cardiovascular Hospital, shown through the regression coefficient $(b 3)=0.383$ and $t$ arithmetic $=4.408$ with sig. $<0.05$.

\section{Recommendations}

The next researcher is expected to be able to further develop this research and make additional factors that enable other strategies besides generic porters in seeing the effect of impact in creating customer loyalty. In addition, further research is expected to be able to examine more complete methods such as the classic assumption test, the statistical t test, the statistical test $\mathrm{f}$. This research was conducted in a covid-19 pandemic situation, space and in conducting data collection through surveys were very limited and fast so the results were not in line with the researchers' expectations.

\section{REFERENCE}

Polyclinic MCU XYZ Cardiovascular Hospital(Mei 2020)

Hospital Growth in Indonesia. http://manajemenrumahsakit.net.(di akses 4 Mei 2020)

Ali, H (2020) Modul 8. Business Strategy Differentiation Cost Leadership, and Integration.Universitas Mercu Buana Jakarta

David, Fred R. 2011. Strategic Management Manajemen Strategi Konsep, Edisi 13. Jakarta: Salemba Empat.

Umar, Husein. 2003. Strategic Management in Action. Penerbit PT. Gramedia Pustaka Utama, Jakarta

Kotler, Philip and Armstrong, Gary. 2012. Prinsip-prinsip Pemasaran. Jakarta: Erlangga Sugiyono. 2017. Metode Penelitian Kuantitatif, Kualitatif, dan R\&D. Bandung: Alfabeta.

Ghozali, Imam. (2016). Aplikasi Analisis Multivariete Dengan Program IBM SPSS 23. Yogyakarta: Universitas Diponegoro.

Rahmayanty, Nina. 2010. Manajemen Pelayanan Prima, Mencegah Pembelotan Dan Membangun Costumer Loyality. Yogyakarta: Golden Ilmu. 